\title{
Memoria historiografiada y memoria materializada. Problemas en la percepción del pasado andino preeuropeo
}

Peter KAUlicke ${ }^{1}$

\section{RESUMEN}

Se presentan formas de memoria y se indaga sobre su relación con la historia, con el fin de aplicar estos conceptos a la forma de visiones del pasado de los incas. De este modo, se formulan niveles que ordenan el pasado en ciclos que vinculan el mundo de los dioses con los incas "históricos". La memoria es de importancia fundamental para consolidar el papel del gobernante y para preparar su futuro destino de ancestro. La ancestralización, por ende, es de relevancia fundamental para la legitimación del poder y de su perpetuación. En dos casos, Pisac y Sipán, se presentan formas de ancestralización del paisaje y de la corporalidad que demuestran facetas diferentes, cambios en la conceptualización y su relación con la élite. En este sentido, la memoria se forma con las élites y comparte su ocaso, pero retiene o reutiliza memorias previas.

Palabras claves: conceptos de memoria - conciencia histórica - historiografía andina - ancestralidad - Pisac Sipán.

\begin{abstract}
This paper enquires how different types of memory relate to history, and applies resulting concepts to reach a greater understanding of the way the Incas might have envisioned their past. A series of levels are formulated in this manner, ordering the past into cycles that link the world of the gods with the "historical" Incas. Memory is fundamental to the reinforcement of the ruler and his future role as ancestor. Hence, 'ancestralization' is basic to the legitimation and perpetuation of power. The cases of Pisac and Sipan reveal forms of ancestralizing the landscape and corporality that are differently faceted, with conceptual differences and their links to the elite. Memory comes into being with elites and shares their downfall, but it always retains or reuses parts of previous memories.
\end{abstract}

Key words: concepts of memory - historical consciousness - Andean historiography - ancestrality - Pisac - Sipan.

Recibido: marzo 2004. Manuscrito revisado aceptado: junio 2004.

1 Departamento de Humanidades, Especialidad Arqueología, Pontificia Universidad Católica del Perú. Apto. 1761, Lima 100, PERU. Email: pkaulic@ pucp.edu.pe

\section{Introducción}

El término "memoria" está de moda; también en la etnohistoria andina y, en menor escala, en la arqueología respectiva. Los usos de este término, sin embargo, varían acercándolo a una especie de sinónimo de mito, identidad, tradición o aun historia sin que, por regla, se especifique en qué radica su beneficio analítico o teórico como alternativa viable y diferenciada a los términos nombrados. "Memoria" es tratada en muchas disciplinas como sociología, historia, literatura, antropología, psicología, historia del arte, ciencias políticas y otras, se la estudia en sociedades simples y complejas, desde arriba hacia abajo y viceversa, así como dentro de un espacio geográfico amplio, por lo cual los estudios respectivos suelen ser no paradigmáticos, transdisciplinarios, sin centro propio (Olick y Robbins 1998: 106). Como memoria social, incluye temporalidad, mente, narrativa e historicidad, los estudios respectivos se mantienen cercanos a la filosofía (Olick y Robbins 1998: 109). Por otro lado, se mantiene la memoria individual, basada en la psicología, la que, de una manera algo difusa, también influye en la definición de un pasado imaginado como cadena de estados traumáticos.

Lo que nos interesa es la relación que tiene la memoria con la historia. Por lo general, la historiografía tradicional se centra en las res gestae, en la descripción de acciones y actores ubicados en espacios temporales definidos, que reclaman realidad y, por tanto, verdad, a lo que se oponen las res fictae, la poesía y, por ende, la ficción, la invención y, por último, la mentira (véase Koselleck 1993: 267-268). Estas invenciones frecuentemente se consideran como manipulación dentro del campo de la política, cuyos fines se centran en el poder.

Muchos enfoques de historia "oficial", sin embargo, precisamente apoyan la construcción de nacionalismos $\mathrm{y}$, por tanto, legitiman el poder en forma de identidades ficticias. 
"La Historia está escrita por autores en el presente, los que se guían por motivos particulares, por lo que la selección e interpretación de sus 'fuentes' siempre son arbitrarias. Si, además, la 'experiencia' está inserta en narrativas, se impide la recuperación de experiencia original. La diferenciación entre historia y memoria, por tanto, es más materia del poder de una disciplina que la de un privilegio epistemológico" (Olick y Robbins 1998: 110).

Una posición frente a la memoria sostiene que ésta se basa en percepciones de personas o comunidades, caracterizadas por la oralidad, como una especie de estado "pre-histórico", no solamente en el sentido de no haber alcanzado la textualidad como precondición de historia, sino tampoco una conciencia histórica al permanecer en un estado básicamente inalterado, en una indiferenciación entre realidad y ficción, dentro de una atemporalidad, en espacios inalterados. Por otro lado, se la entiende como categoría metahistórica que abarca historia oral, popular, folk, mito y asimismo reúne conceptos como naturaleza, cultura y lengua de tal modo que memoria comienza a redefinir los límites de historia en los discursos postmodernos (Klein 2000: 128).

Una forma de memoria, llamada "memoria colectiva", se basa en Les cadres sociaux de la mémoire de Maurice Halbwachs (véase Halbwachs 1975, 1991), publicado en 1925, que se hizo popular en la década de los '80. Halbwachs sostiene que la memoria está condicionada por su contexto social. Si bien es, obviamente, individual, las experiencias individuales se fusionan con las adquiridas o comunicadas, lo cual no solamente define lo que se retiene, sino también lo que se olvida. La memoria, por tanto, "vive" y se mantiene en la comunicación, cambios en la realidad comunicada que resultan en una ruptura de la comunicación y llevan al olvido. Es, en consecuencia, un conocimiento compartido y mantenido entre individuos de un grupo social.

Las ideas de la memoria requieren una objetivación en forma de símbolos para, de esta manera, insertarse en el sistema de ideas compartidas. Estos símbolos se repiten periódicamente en fiestas, convirtiéndolos en tiempo vivido colectivamente, dentro de un espacio que sirve de marco referencial. Este espacio también incluye el mundo de objetos que ofrecen un cuadro de permanencia y estabilidad. La memoria requiere la presencia de lugares, y tiende a convertirse en espacio. Con ello, también se define como la productora de identidad. Todo ello implica también que la memoria "reconstruye" y reorganiza el pasado, y al hacerlo también organiza la experiencia del presente y del futuro. Según Halbwachs, estas características se oponen a lo que es la historia. Mientras la memoria enfatiza continuidad, la historia enfatiza cambios, donde la memoria cesa, comienza la historia (véase Assmann 2000a: 3447). Este concepto se opone claramente a otras memorias colectivas que parten del supuesto de que la memoria es una herencia biológica y una "memoria involuntaria" que se manifiesta en sueños y en el subconsciente (Assmann 2000a: 47).

Assmann (2000a: 48-86, 293-301; 2000b) propone dos formas de memoria colectiva: la memoria comunicativa y la memoria cultural. La primera abarca el tiempo generacional, se crea y desaparece con los que lo comparten, el cual corresponde a un lapso de 80 a 100 años (tres a cuatro generaciones), sean éstas sociedades con o sin escritura, y se refleja también en la estructuración de las genealogías. La memoria colectiva funciona en forma bimodal: en la memoria que se refiere a los orígenes y en el modo de la memoria biográfica. La primera se incorpora en objetivaciones idiomáticas y no idiomáticas como rituales, bailes, mitos, formas de ornamentación, vestido, adorno, caminos, marcas, paisajes, entre otros, que cumplen funciones mnemotécnicas. El modo de la memoria biográfica, en cambio, se basa en la interacción social.

La memoria cultural se concentra en puntos fijos del pasado como migraciones, toma de tierra, exilios o éxodos. También los mitos son "figuras de memoria". De este modo, la historia se convierte en mito a través de la memoria, lo cual no implica una conversión hacia lo irreal, sino, al contrario, constituye una fuerza normativa y formativa perpetuada. En este sentido la memoria cultural tiene un carácter sagrado, manifestado en su presentación en fiestas, en una comunicación exaltada, separada de la diaria o común. Requiere, por tanto, de portadores con conocimiento ritual preciso, convirtiéndola en una forma exclusiva, al distanciarse de la memoria comunicativa comparable a la diferencia entre un habla oficial y otro común.

Otro aspecto fundamental para la memoria es el culto de los muertos. La muerte, obviamente, es 
la experiencia primordial de la diferenciación entre el pasado y el presente. Se presenta en forma retrospectiva y prospectiva. La primera se refiere a la forma como un grupo vive con sus muertos y los memoriza; la otra es la exaltación del muerto con el fin de perpetuar su fama y sus logros. Es, por tanto, un poderoso motor que funda identidad (Assmann 2000a: 60-63; véase más adelante). Un último aspecto es la relación entre memoria y élite. La élite trata de reducir la laguna que existe entre la experiencia comunicativa y la de origen por la necesidad de legitimación; Assmann (2000a: 71) llama a este aspecto también memoria retrospectiva. Asimismo, hay un aspecto prospectivo que consiste en su perpetuación por medio de monumentos $\mathrm{u}$ otras formas de memoria.

Esta introducción larga no pretende haber presentado toda la gama de conceptos o formas de memoria. Más bien señala pautas que podrían abrir caminos más seguros con el fin de evitar la perpetuación de definiciones difusas o la insistencia en antagonismos anacrónicos en cuanto a la aplicación al tema de la memoria colectiva y cultural en los Andes Centrales. Los conceptos presentados permiten matizar, así como incluir, el enorme universo del pasado preincaico, al que etnohistoriadores, antropólogos sociales o etnógrafos suelen tener poco acceso.

\section{Memoria historiografiada y memoria materializada}

Antes de entrar al tema específico cabe definir lo que llamo "memoria historiografiada" y "memoria materializada". El primer término indaga sobre conceptos de conciencia histórica de la élite incaica en su relación entre memoria biográfica y memoria de origen como visión "auténtica" o como "falsificación" por parte de los españoles. Asimismo, constituye una forma de "historizar" la memoria colectiva al analizarla en segmentos cronológicos (p.e., los 500 años entre la Colonia y el presente; véase Abercrombie 1998).

Si la memoria colectiva es una forma de identidad por medio de experiencias compartidas y aprendidas, dentro de un contexto social específico, significa esto que se trata de un ideal que reclama perpetuidad absoluta, pero esta identidad también se modifica, se transforma o se olvida. En consecuencia, existen diferentes memorias en diferentes sociedades o grupos sociales que se si- guen en el tiempo (o coexisten), y en este tiempo olvidan y ganan nuevas experiencias. La perpetuación ilimitada es la ilusión de un grupo concreto, solo la memoria cultural posee mecanismos de retención complejos y más eficientes, ya que son más exclusivos, pero los grupos dominados, oprimidos y no privilegiados inducen al cambio. La "historia lineal", por tanto, es más bien un síndrome de las clases bajas (Assmann 2000a: 72).

La "memoria materializada" se centra en la materialidad de lo "memorizable", con lo cual me refiero a las formas materiales de memoria colectiva que cumplen una función mnemotécnica. Estas formas suelen relacionarse con monumentos. Le Goff (1991: 227) explica este término latín que proviene de mens, memini o "mente" y "memoria" y monere que significa "hacer recordar", "avisar", "iluminar", "instruir". Para los romanos, monumentum era una obra de arquitectura conmemorativa, relacionada a eventos y personas como vestigios de la memoria cultural en su aspecto prospectivo (véase arriba), así como materialización de conceptos relacionados con la muerte.

Ambas formas de materialización pueden relacionarse tanto con la memoria biográfica como con la memoria de los orígenes. Su marco referencial es el espacio. Este espacio en sí es una materialización del tiempo, un producto de constantes cambios tanto en su aspecto "natural" como "cultural", cuya interpretación depende de los conceptos sociológicos y cosmológicos de grupos sociales que ocupan este espacio. En este sentido, se debería diferenciar entre la modificación intencional del espacio y el uso del espacio memorizado. La primera se debe a grupos interesados en perpetuar una memoria cultural que agrega una nueva memoria como continuación de la anterior, con la cual no necesariamente existe un vínculo "histórico", sino una revinculación que implica una invención dentro de la conciencia histórica. Estos intereses, por ende, implican, en particular, a las élites. Tales reinterpretaciones, sin embargo, también valen para aquellos grupos que se caracterizan por la memoria comunicativa o colectiva cuyas modificaciones del espacio son menores y más ligadas al espacio como escenario de rituales, lo cual incluye también los lugares "naturales". ${ }^{2}$

2 Para una interpretación arqueológica véase Bradley (2000). 
Esta conceptualización de espacio como tiempo con formas de memoria materializada requiere su textualización y/o contextualización, en cierto sentido la verbalización de lo material que implica su significación. Conviene remarcar que la lengua también está sometida a cambios, por lo cual no debe tomarse como otra estructura supuestamente inalterada que "comprueba" la inalteración de los demás conceptos mencionados. Se trata, en cambio, de "procesos de cambios comunicativos que se manifiestan en constelaciones histórico-comunicativas diferentes en lugares diferentes con tradiciones discursivas e intensidad diferentes" (Oesterreicher 2001: 234).

En resumen, la "memoria historiografiada" y la "memoria materializada" deben tomarse como intentos de evitar discursos modernos que se sirven de la memoria con el fin de postular pensamientos y sus realizaciones discursivas o materializadas supuestamente inafectadas por el tiempo y el cambio referente a conceptos del pasado en el presente. Tales supuestos suelen "exotizar" al "otro" y llevan a la justificación de la presencia de "ciencias ocultas" como remanentes primordiales manifestadas en el reciente "neochamanismo" o "new age", así como de rituales inventados como el Inti Raymi y muchos otros cuya dramaturgia se basa en reinterpretaciones de textos de los siglos XVI y XVII y de imágenes prestadas de la imaginería colonial mezcladas con motivos prestados de objetos arqueológicos incaicos y preincaicos. No existe una sola memoria, "colectiva" o no colectiva, sino muchas que coexisten o se siguen tanto como no existen espacios inalterados, o conceptos inamovibles llámense identidad, tiempo, naturaleza, lengua o cultura.

En lo que sigue quiero ilustrar brevemente lo expuesto con ejemplos de los Andes Centrales, concentrándome en el siglo XVI y en el tiempo preincaico.

\section{La memoria del "otro" en el siglo XVI}

La confrontación entre españoles y pueblos andinos que se produce en el siglo XVI es, entre otras cosas, también una confrontación entre memorias. De parte de los españoles son, en primer lugar, formas de experiencias individuales que se insertan dentro de conceptualizaciones del "otro" a partir de una autopercepción diferenciada (memoria biográfica europea), a menudo textualizada desde una distancia temporal considerable (p.e., Garcilaso de la Vega, Pedro Pizarro, entre otros). Otros textos tienen carácter más oficial, a modo de un cuestionario cuyas preguntas no apuntan prioritariamente a una veracidad de los testimonios de los encuestados (ni de una traducción y transcripción de lo comunicado), sino a intereses oficiales de orden económico, administrativo o eclesiástico (relaciones geográficas, visitas, pleitos, litigios, etc.).

En particular la "Extirpación de la Idolatría" produjo una multitud de textos durante un lapso considerable, cuya finalidad era la aniquilación de la memoria:

"Extirpar se aplica, y se aplicaba, en particular a las malas hierbas, con las que eran comparadas las religiones paganas -andinas en nuestro caso- junto con los comportamientos, rituales, dogmas y representaciones que correspondían, y que la Iglesia quería desarraigar para poder sembrar y plantar luego en tierra despejada" (Duviols 2003: 21).

No se trata solo de la detección y del castigo de los culpables, sino de la destrucción masiva de los "ídolos", los símbolos materiales de la religión y de la memoria. Esta destrucción ha dejado el extraño efecto hacia una supuesta tendencia incaica de una abstracción casi anicónica y parca que reduce los seres numinosos a entes borrosos con funciones e interrelaciones difusas, ya que suelen "traducirse" en el vocabulario de la demoniología del Renacimiento y de la Edad Media. Esta manifiesta parquedad contrasta vivamente con el Area Mesoamericana donde la información contemporánea, tanto gráfica como textual, permite definir una multitud de divinidades cuyas imágenes, funciones y contextos míticos y rituales permiten, entre otras cosas, trazar sus orígenes en un pasado preazteca igualmente abundante en imágenes. Como el pasado preincaico también es rico en imágenes, probablemente religiosas, lo incaico se convertiría en una excepción de percepción religiosa difícil de explicar.

Por otro lado, los textos de la Extirpación proveen información dispersa y diversificada que requieren lecturas críticas de los discursos escondidos en la enorme cantidad de información que no solamente se limitan a topoi comunes en el vocabulario tradicional de los extirpadores. 
Otro género es el conjunto de las llamadas crónicas, versiones cronologizadas de las res gestae de los conquistadores, cuyo prólogo y justificación se centran en la historia de los gobernantes incaicos. Estas crónicas presentan un género de larga tradición en la Edad Media, cuyas listas de reyes se inician como personajes míticos de la antigüedad y de la mitología regional. Las referencias al pasado incaico se basan en testimonios orales de miembros de la aristocracia incaica, apoyados por quipus que también figuran como formas mnemotécnicas en las encuestas estadísticas de las visitas y en los litigios. Estas obras se caracterizan por varias técnicas tanto de la transmisión como de la omisión o exclusión. Esta última se percibe claramente en el tratamiento sumamente escueto de la memoria de los orígenes.

El origen del mundo y las res gestae de los dioses que se vinculan con un espacio mítico y sagrado, pero a la vez real -el lago Titicaca y el sitio de Tiwanaku-, deben haberse plasmado en una multitud de textos que los españoles reducen a resúmenes sumamente escuetos. El segundo nivel de mitos que se refieren al origen de los incas está tratado más extensamente, pero también pecan por lo elemental, ya que se descubren numerosas variantes, probablemente reflejos débiles de secuencias míticas complejas. Solo el tercer nivel, el del inicio de la última "dinastía" de los incas "históricos", recibe una atención más detenida. Este tratamiento tiene otra desventaja que es la exclusión de memorias no incaicas que resulta en un principio común que es la homogeneización en una especie de modelo de interpretación española que esconde una "interculturalidad" evidentemente presente en el mundo incaico. Esta interculturalidad se expresa en la presencia de espacios, idiomas y memorias diferentes de élites y grupos sociales diferentes a los incas. Una homogeneización parecida vale para la terminología empleada. A modo de ejemplo, el término waka, de importancia central para la memoria o las memorias andinas, resume, en la percepción de los españoles, conceptos y objetos muy diferenciados de importancia fundamental para los indígenas. ${ }^{3}$

Este procedimiento homogeneizador permite la conexión o fusión entre informaciones de distin-

3 Véase van der Guchte (1990: 237-271) y Ramírez (2002: 232-234, 262-279). tas áreas y sociedades, de distintos niveles sociales y aun de diferentes tiempos al incluir información "arqueológica" obtenida por el saqueo de contextos funerarios preincaicos (Kaulicke 1997: 8-9). Las resultantes imprecisiones, lamentablemente, suelen ser adoptadas acríticamente por muchos etnohistoriadores, arqueólogos y antropólogos.

Estas limitaciones complican una clara diferenciación entre "historia española" vs. "historia incaica", "historia" vs. "mito", así como "oralidad" $v s$. "escrituralidad", por lo que obligan a una lectura detenida de los textos. Julien (2000) se dedicó a esta tarea; ella detecta coherencias en los discursos y en las secuencias narrativas que se basan tanto en la oralidad como en el uso regular de quipus, i.e., codificaciones que permiten una estructuración lógica en un lenguaje exaltado y, como veremos, ritualizado.

Quisiera concentrarme en un texto particular, el de Juan de Betanzos, llamado "Suma y narración de los yngas que los yndios nombraron Capac Cuna que fueron señores en la ciudad del Cuzco y de todo lo a ella sujeto....en la cual Suma se contienen las vidas y hechos de los Yngas Capac Cuna pasados nuevamente traducido e recopilado de lengua india de los naturales del Piru..." (Betanzos 1987 [1551]). Esta "Suma" difiere de otras versiones historiográficas por su énfasis en lo ritual, lo cual le da un aspecto más "auténtico" al respetar la o las versiones originales como lo sostiene el propio Betanzos.

La memoria se centra en el Capac Inca, el término yupanqui ("alguien honrado"), el nombre de Pachacutec, se relaciona con yupaycha que significa "conmemorar, celebrar los méritos de alguien". El Inca, en consecuencia, es tanto el beneficiario como el productor de la memoria a través de los quipus (Kaulicke 2000: 10). Las narrativas que adquieren una calidad épica, caracterizadas como life histories por Julien, no solamente se concentran en los éxitos bélicos que resultan en una atracción especial para los españoles.

Los capaccuna llevan vidas ejemplares en las que tienen que cumplir papeles fundamentales. Estos son los de guerrero, de cazador, de constructor y de renovador. En el primer papel, el capac inca vence a los enemigos con la ayuda de los dioses y de sus ancestros. El tratamiento de los enemi- 
gos vencidos corresponde a la aniquilación y/o apoderamiento de su memoria (conversión de los cuerpos en trofeos, antropofagia, negación de enterramiento). Los mismos actos bélicos tienen carácter ritual, probablemente relacionados con fechas apropiadas de un calendario ritual no especificado por Betanzos. El papel del cazador no está tan extensamente tratado pero tiene parecidos compartidos con el primero. Por un lado, ciertos animales son requeridos para los sacrificios, otros como "tigueres" sirven para devorar a los enemigos prisioneros. El propio Inca se vincula con felinos, aves y otros animales; el napa, un camélido vestido, aún le representa como alter ego. El tercer papel, el del constructor, es de mayor importancia. Edificios como templos, palacios y fortalezas, así como ciudades se construyen gracias a la intervención directa del Inca que los planifica, organiza y los ejecuta en el afán de superar las obras sus antepasados con el fin de que "le sea cosa memorable". Todo ello se lleva a cabo dentro de un marco ritualizado. El aspecto de la renovación se vincula con el de la construcción al que se agrega la renovación del culto, en especial el de los antepasados. Son, sobre todo, Pachacuti y luego Huayna Capac, los que se destacan en este papel.

Estos papeles se insertan en dos ciclos, uno relacionado con la memoria biográfica, en forma de la ritualización de cambio de identidades que suceden con ritos públicos relacionados con el nacimiento, ascenso al poder y con la muerte. Esta última es de importancia fundamental, ya que implica la transformación en ancestro, en portador de una energía llamada illa que es literalmente vital para la sociedad. La imagen -no necesariamente su cuerpo momificado- se convierte en símbolo participador de la sociedad, en una especie de historia visual. El otro ciclo se inicia con Pachacuti quien de renovador y legislador pasa al de antepasado, manifestado con un énfasis especial en los complejos ritos funerarios, iniciados por él, la purucaya. Tupac Inca se relaciona más con el papel de sinchi y se relaciona con los ritos de transmisión de mando. Huayna Capac, finalmente, se asocia al papel de renovador y su presencia en ritos de nacimiento. Este ciclo mayor, claramente se inicia con una repetición o regeneración del mito de origen y relaciona el nombre de Pachacuti con el concepto homónimo que suele interpretarse como catástrofe, diluvio o fin del mundo, el apocalipsis o un ciclo de 500 años. Me parece que la raíz cuti, que se vincula con "volver, mirar hacia atrás, restituir o volver a otro lo que es suyo" y el concepto de "pacha" como tiempo-mundo, abre la posibilidad de una recreación del mundo, una especie de renacimiento, después de crisis originadas por capaccuna, quienes no cumplen bien con sus papeles como en los casos de Viracocha y de Huayna Capac.

Esta interpretación permite la detección de varios de estos ciclos: el primero se inicia con la creación del mundo y las hazañas de los dioses, el segundo se inicia con un éxodo y el nacimiento de los ancestros primordiales y termina con Viracocha, el tercero es el ya referido y el cuarto, el único totalmente "histórico", se inicia con Atahualpa y termina con la muerte de Sayri Tupac Yupanqui. ${ }^{4}$

Estos conceptos tienen un paralelo sorprendentemente estrecho con el Egipto Antiguo -naturalmente no intencionado por Betanzos-e insertan estos ciclos en una linealidad que no hace dudar de la existencia de un complejo "arte de memoria" y una conciencia histórica que se consolida en la historia a través del mito y del rito.

\section{La memoria preincaica}

El segundo tema propuesto se centra en la percepción de memorias anteriores a los incas a través de lo que llamo "memorias materializadas" que se centran en enfoques críticos dentro del campo de la arqueología. Para diferenciar lo incaico de lo preincaico es preciso definir primero lo incaico en su materialización. Esto aparenta ser fácil, ya que los estilos plasmados en arquitectura, cerámica, metal, tejidos, entre otros, son definidos desde hace mucho tiempo. Su relación con la historiografía o su memoria, sin embargo, resultan más difíciles en su definición precisa.

Generalmente los datos historiográficos, muy debatidos entre los etnohistoriadores en cuanto a su contenido "histórico", se aceptan sin discusión entre los arqueólogos cuyos conocimientos de causa suelen ser reducidos de tal modo que no solamente se acepta a los incas "históricos", sino se les atribuye obras de acuerdo a los datos contenidos en las fuentes de los siglos XVI y XVII.

Véase Kaulicke (1998, 2000). 
Este procedimiento, en consecuencia, se constituye como argumento circular carente de crítica científica. Niles (1999) define un estilo arquitectónico atribuido a Huayna Capac que, según ella, se diferencia de los estilos "personales" de sus antecesores, con lo cual estas obras se convierten en monumentos en su definición "clásica".

Desde un punto de vista arqueológico se deberían presentar pruebas concluyentes basadas en la cronología relativa. ¿Qué argumentos existen para definir la distancia temporal entre obras de los diferentes estilos incaicos? ¿Cuáles son los cambios, no solamente estilísticos sino también funcionales, espaciales y contextuales? ¿Qué es un templo, una fortaleza, un palacio, en la conceptualización incaica plasmada en sus materializaciones concretas? ¿En qué modo los ritos descritos en las fuentes se insertan en la materialidad del espacio cultural? ¿En qué forma este espacio se mantiene intacto y,en qué forma se modifica o se reestructura? ¿Estas modificaciones implican vestigios preincaicos y, en caso que sí, en qué forma se presentan?

El primer problema es el registro arqueológico de las evidencias (Figura 1). De la ciudad incaica del Cuzco se percibe una destrucción de un 90\% (Paredes 1999: 197), y de las pocas excavaciones modernas dispersas y reducidas suelen haber pocos datos disponibles. El imponente paisaje ritual hacia el noroeste de la ciudad, lleno de rocas esculpidas y estructuras monumentales como Sacsayhuaman, tampoco ha sido documentado debidamente y guarda aún mucho de su potencial como espacio de la memoria cultural. Esta escasez de datos arqueológicos conlleva a la imposibilidad de una evaluación crítica ${ }^{5}$ e independiente de los datos etnohistóricos, la falta de excavaciones documentadas esconde la contextualidad necesaria en cuanto a la funcionalidad y a aspectos materiales de lo ritual-ceremonial.

En cuanto a lo preincaico conviene primero indagar sobre la relación entre los incas y Tiwanaku, el centro del mundo y el lugar de origen por excelencia. En sus primeros dos capítulos Betanzos recoge mitos locales -aparentemente no versiones "oficiales"- acerca de seres míticos llamados viracochas y los vincula con ancestros petrifica-

\footnotetext{
Véase van der Guchte (1990).
}

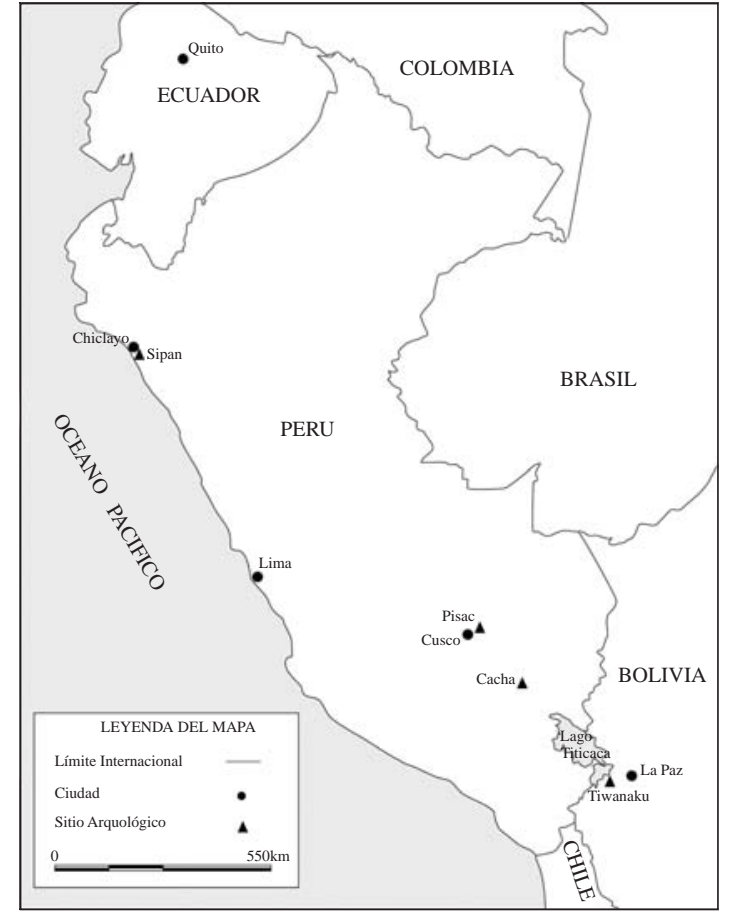

Figura 1. Mapa con los sitios mencionados en el texto.

dos. No es difícil relacionarlos con las enormes estatuas líticas en Tiwanaku que deben haber sido mucho más numerosas en los tiempos incaicos que en la actualidad. Se trata de representaciones antropomorfas en posiciones ritualizadas con vestimentas largas y decoradas con imágenes de seres míticos que los arqueólogos suelen llamar Viracocha. De ahí es probable que las estatuas mismas no sean representaciones de seres míticos, sino más bien gobernantes-sacerdotes que perpetúan actos rituales en espacios ceremoniales (Kaulicke 2001a: 508).

La presencia inca es palpable en Tiwanaku, así como en la Isla del Sol y en Copacabana, donde hubo un gran centro incaico de peregrinaje. En toda esta zona y en las aguas del Titicaca que rodean la isla (ofrendas subacuáticas de cerámica, oro y piedra) los vestigios de la ocupación tiwanaku son tan densos que también es probable que haya existido un centro ceremonial tiwanaku con anterioridad, mientras que no parece haber ocupaciones postiwanaku y preinca (Bauer y Stanish 2001). Betanzos también describe un adoratorio en Cacha (Raqchi) con una estatua grande erigida en conmemoración de Viracocha que castigó a la zona por no obedecerle. Sillar 
(2002) informa de la presencia de sitios con cerámica tiwanaku de gran calidad y Cerrón-Palomino (com. pers. 2000) encuentra toponimios puquina en la zona, en un idioma que, según él, fue hablado en Tiwanaku, ${ }^{6}$ lo cual no impide la interpretación de que los mitos recogidos por Betanzos reflejen memorias a incursiones militares desde el altiplano.

Buck (1935) presenta el fragmento de un aríbalo del estilo Inca con decoraciones pintadas que imitan el estilo Tiwanaku IV/V. Valcárcel (1935) excavó un kero con motivos parecidos en Sacsayhuaman. Todos estos datos a los que se agregan evidencias múltiples de emulaciones Tiwanaku en la arquitectura incaica sugieren una preocupación constante de la élite incaica en vincularse con un pasado normativo en su búsqueda de legitimación.

Como los quipus, tan importantes para la estructuración del pasado incaico, se remontan al Horizonte Medio, la información memorizada disponible a los incas podría haber sido mucho más rica que lo que reflejan los trozos de la mitología popular, fruto de una memoria colectiva algo parecida a los conceptos modernos de las poblaciones altiplánicas (Abercrombie 1998). Cabe mencionar que las estatuas antropomorfas de Tiwanaku forman la parte final de una larga tradición que caracteriza la cuenca del Titicaca y se inicia en el Formativo: la tradición Yaya Mama. Stanish (2003), probablemente con razón, las vincula con expresiones de las élites de la subárea circumtiticaca, normalmente relacionadas con espacios ceremoniales.

\section{Los ancestros y la memoria}

En la discusión acerca de la conciencia histórica incaica se enfatizó la relevancia fundamental de la memoria del Inca como vehículo para su preparación como ancestro y el papel preponderante de sus antecesores como ancestros en la vida política e ideológica dentro de un paisaje cultural central marcado por su presencia. Este concepto de ancestralización se centra en conceptos de corporalidad que se expresa en manifestaciones complejas que van desde el cuerpo "curado" a su "bulto" con cabellos y uñas y a imágenes áureas

6 Véase Kaulicke (2001a). $\mathrm{y}$, finalmente, petrificadas en espacios que van desde la estructura funeraria al centro políticocultural del Cuzco (Coricancha, Aucaypata, rituales en la cercanía del Cuzco y presencia en actividades bélicas, entre otros, fuera del Cuzco) y marcadores en el paisaje que constituye y organiza el mundo social. Estas imágenes reciben una atención constante con personal permanente con el fin de garantizar su bienestar y de encargarse de la perpetuación de su memoria. Son, además, objetos de renovación constante que coincide con la renovación del culto y la renovación del mundo a cargo de cada gobernante nuevo. Reciben ropa nueva y regalos y se renueva su memoria.

Estas transformaciones y renovaciones dentro de complejas secuencias rituales son manifestaciones de la memoria cultural cuyo funcionamiento depende de los linajes respectivos y del inca gobernante. La distancia temporal conlleva reinterpretaciones de estatus y a una cierta despersonalización o su conversión de ancestros como antepasados a ancestros divinizados, lo cual, probablemente, ocurre con la conceptualización incaica de las estatuas de Tiwanaku. Reinterpretaciones parecidas ocurren en los 500 años desde la llegada de los españoles hasta la actualidad. Este proceso está acompañado por cambios en la relación de los ancestros con la sociedad. Desde "diálogos" permanentes marcados por intereses compatibles de la sociedad incaica se llega a un temor continuo de los ancestros despersonalizados, vengativos y lejanos, confundidos en un nebuloso mundo de los orígenes, que domina la actitud actual frente a este fenómeno.

Otro problema relacionado es la definición de los ancestros que no forman parte de la cúspide de una sociedad jerarquizada, así como la de los ancestros no incaicos. Es de esperar que cabezas de linajes, por lo general, se conviertan en ancestros, aunque su transformación y su aparato ritual asociado debería diferenciarse, pero los datos respectivos son tan generales e incompletos que no permiten su caracterización precisa.

Todas estas reflexiones se basan en interpretaciones de fuentes etnohistóricas, por lo que queda por averiguar cuáles son las posibilidades para detectar su materialización en contextos arqueológicos. En vez de volver a insistir en una base de datos que se caracteriza por su estado incompleto 
debido a destrucciones pasadas y modernas, así como documentación fragmentaria o inexistente quisiera presentar, a modo de ejemplo, dos casos relacionados con la ancestralización: Pisac para el área del Cuzco y Sipán para un caso preincaico.

\section{a) Pisac}

Pisac es un sitio incaico extraordinario a unos 40 $\mathrm{km}$ al noreste del Cuzco, cerca del pueblo del mismo nombre, en la margen derecha del río Vilcanota. Según Sarmiento de Gamboa (1960 [1571], cap. 34) se trata de un palacio rural construido por Pachacuti, quien también hizo levantar ahí un templo del Sol en conmemoración a su victoria sobre los cuyos. Autores del siglo XIX, como Squier (1877) y Wiener (1880) retoman la noción de un Templo del Sol, pero enfatizan también su carácter defensivo, Angles (1970) interpreta el sitio como gran ciudad o "metrópoli". En vez de presentar otra hipótesis general quisiera concentrarme en algunos aspectos relacionados con el tema tratado.

La parte central del sitio está constituida por el gran macizo rocoso que forma la cumbre alargada de un cerro (Figura 2). En sus extremos septentrional y meridional se perciben hendiduras aplanadas, donde se han erigido complejos arquitectónicos conocidos como Qallaqasa e Intihuatana. Un gran muro de factura excelente con cuatro portadas enmarca el cerro en su lado oriental. Estas instalaciones convierten el macizo rocoso en centro sagrado enfatizado por el área ceremonial meridional, probablemente un Templo del Sol.

Hacia el noreste y el sureste se levantan construcciones sobre espolones más bajos que comparten un patrón semicircular (Qantus Raqay y Pisaqa), las cuales enmarcan una extensa área de terrazas. Hacia el oeste, el cerro es delimitado por una quebrada profunda, formada por el río Kitamayo que desemboca en el río Vilcanota. En su margen derecho se levanta el farallón del cerro Tantanamarca, en cuya parte septentrional se perciben numerosos grupos de torres funerarias. El extremo norte de este sector que permite visibilidad al horizonte oriental a través de la aplanada mencionada está convertido en un complejo con andenería, series de plazas en el margen derecho del río y restos de muros que encierran el complejo. En su parte superior se perciben estructuras funerarias de factura incaica que reutilizan contextos funerarios anteriores (Figura 3). Estas permiten una buena visibilidad al otro lado donde hay otra serie de terrazas con un dren central, una serie de fuentes, una construcción circular encima de ellas y el sector Qallaqasa con un "muro", resultado de un pliegue tectónico, que lo separa del macizo rocoso del cerro, el cual coincide con el muro meridional que encierra el complejo funerario. Desde un nicho en la parte superior de este último se pueden observar dos cerros en el horizonte que enmarcan la salida del sol que ilumina este sector en las mañanas. A unos $15 \mathrm{~m}$ por debajo de dos construcciones en la parte central superior del complejo mencionado nace un manantial cuyas aguas se recolectan en un canal que corre al pie del área de las torres funerarias y se tuerce hacia una construcción llamada Antachaca, que, por ende, no es puente, como sugiere su nombre quechua, sino acueducto, a unos $20 \mathrm{~m}$ por encima del río, con un ancho de $20.7 \mathrm{~m}$ (Figura 4).

Al lado del cerro de Pisac se observa otro acueducto con tres pilares (Figura 5), así como muros que refuerzan y nivelan el curso del canal hasta entrar en el sector Intihuatana (Figura 6), donde pasan por una serie de fuentes, una de las cuales, excepcionalmente bien trabajada y decorada, conecta con otro canal que se origina en el sector Inka Qonqorina por encima del Intihuatana. Delante de las estructuras de este sector voltea hacia el este y baja bruscamente en una serie de fuentes. Luego se pierde cerca del sector Pisaqa, donde parece unirse con otro canal que proviene de un manantial cerca de una de las portadas del muro de circunvalación.

Esta descripción detallada permite varias interpretaciones relacionadas con el tema. El sitio está compuesto por dos sectores, norte y sur, interconectados por el macizo rocoso del cerro. $\mathrm{La}$ parte norte tiene un eje de visibilidad oeste a este que pasa por el collado norte. El punto focal de este eje es la parte superior del complejo funerario que a su vez forma parte de un cerro llamado Guanacauri, relacionado con "origen" en la conceptualización incaica. Es a la vez el origen del agua "cultural" o la orina de los ancestros, quienes se renuevan diariamente con los rayos del sol.

De acuerdo a la situación arqueológica es, además, una especie de reformulación de la ancestralidad, por reocupar un área funeraria anterior. 


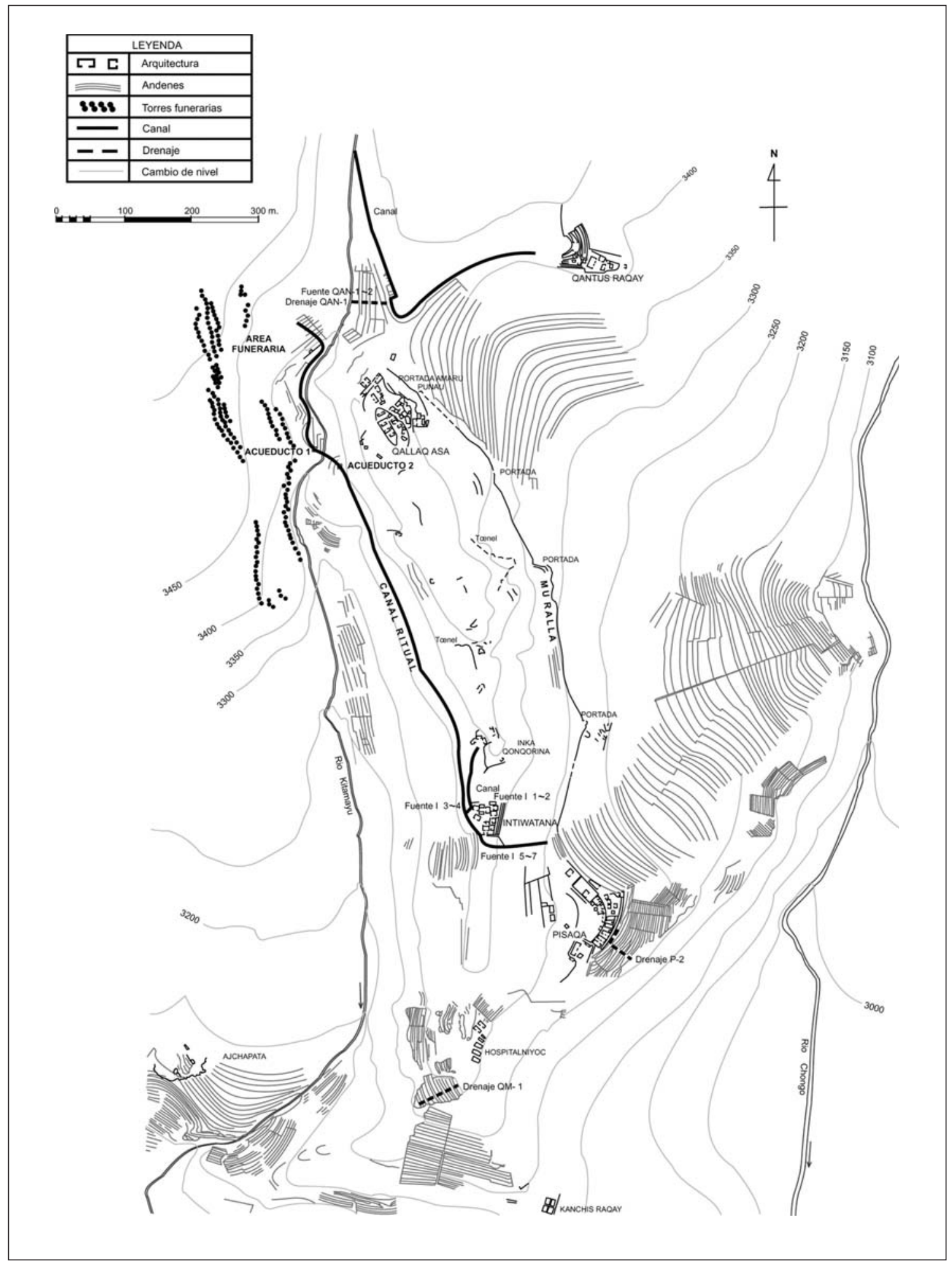

Figura 2. Mapa de Pisac con indicación de los sectores e instalaciones mencionados en el texto (adaptado de Zapata et al. 2001, Figura 2). 


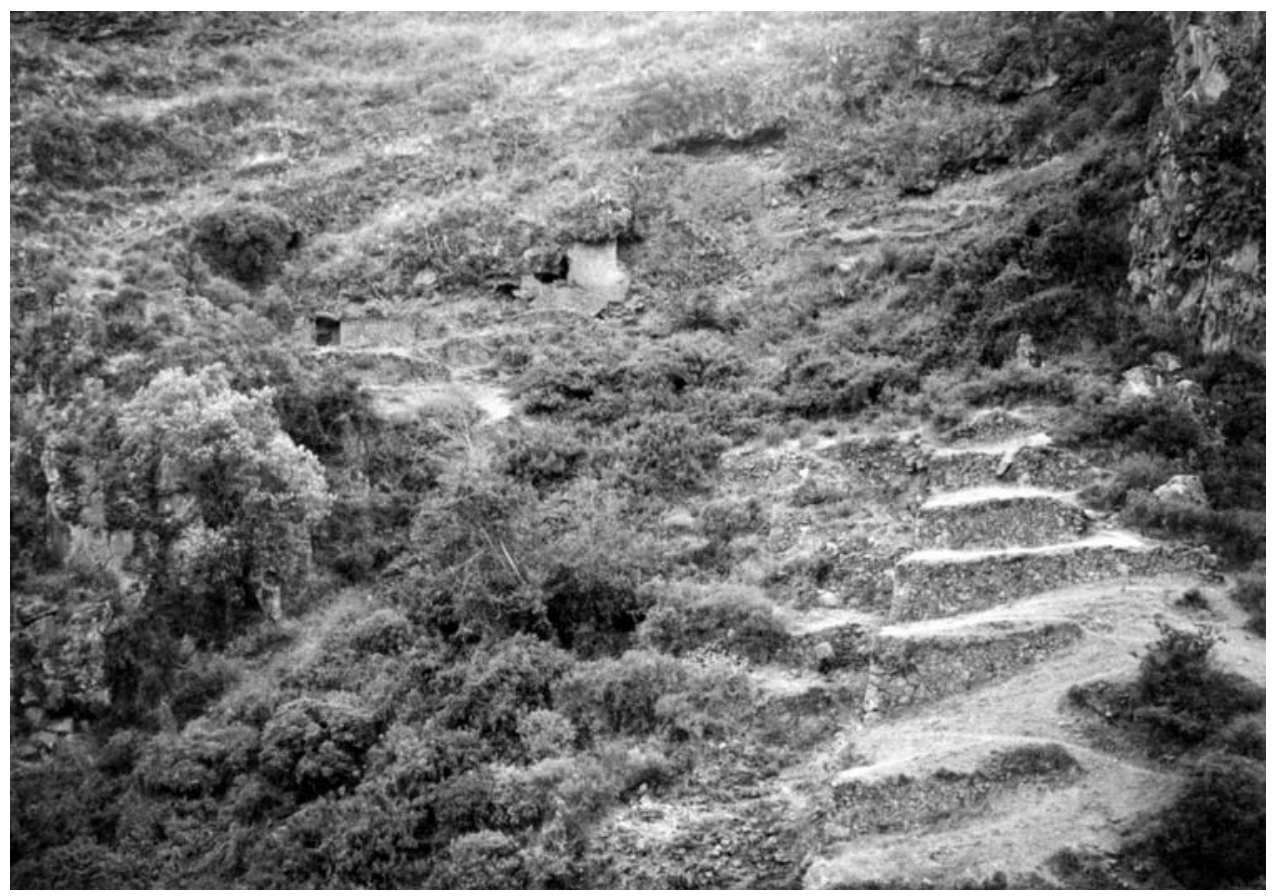

Figura 3. Pisac. Area funeraria con andenes encima del margen derecho del río Kitamayu (para ubicación ver Figura 2). (Foto T. Kusuda).

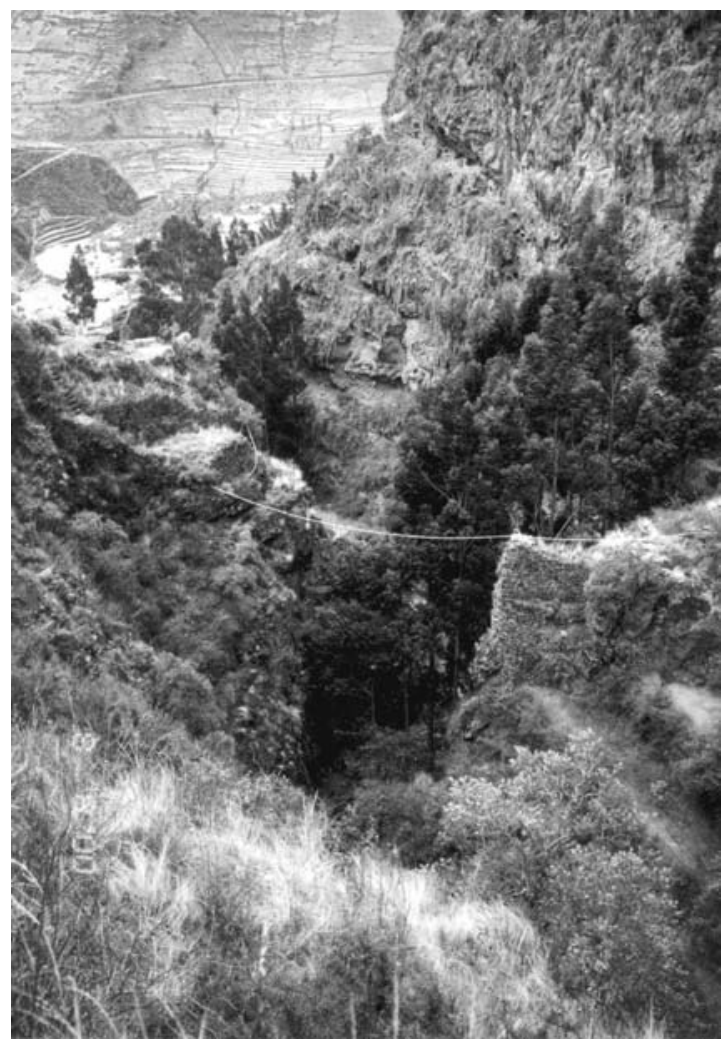

Figura 4. Pisac. Acueducto 1 (Antachaca) visto desde el norte (para ubicación ver Figura 2). (Foto T. Kusuda). 


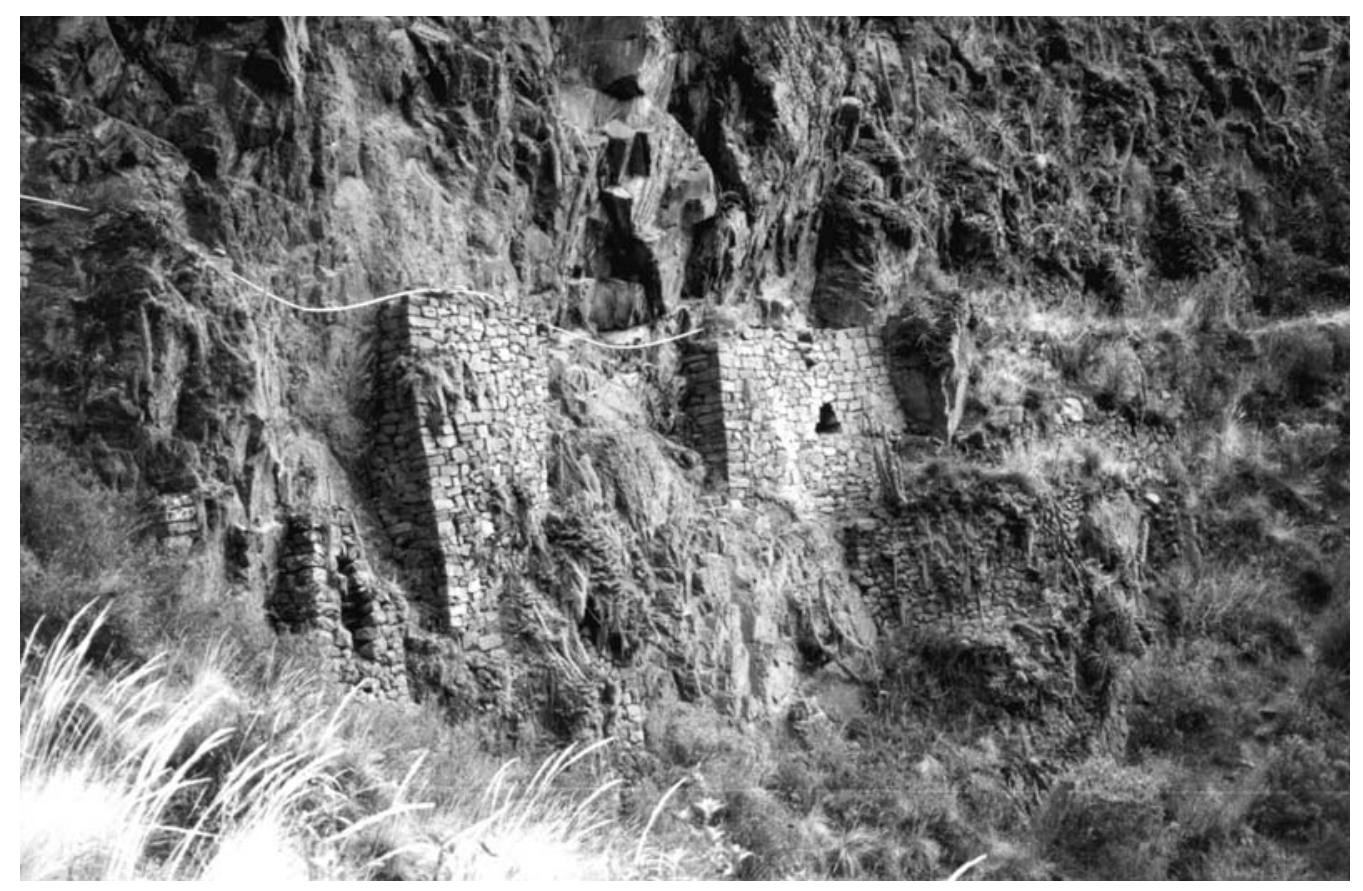

Figura 5. Pisac. Acueducto 2 (para ubicación ver Figura 2). (Foto T. Kusuda).

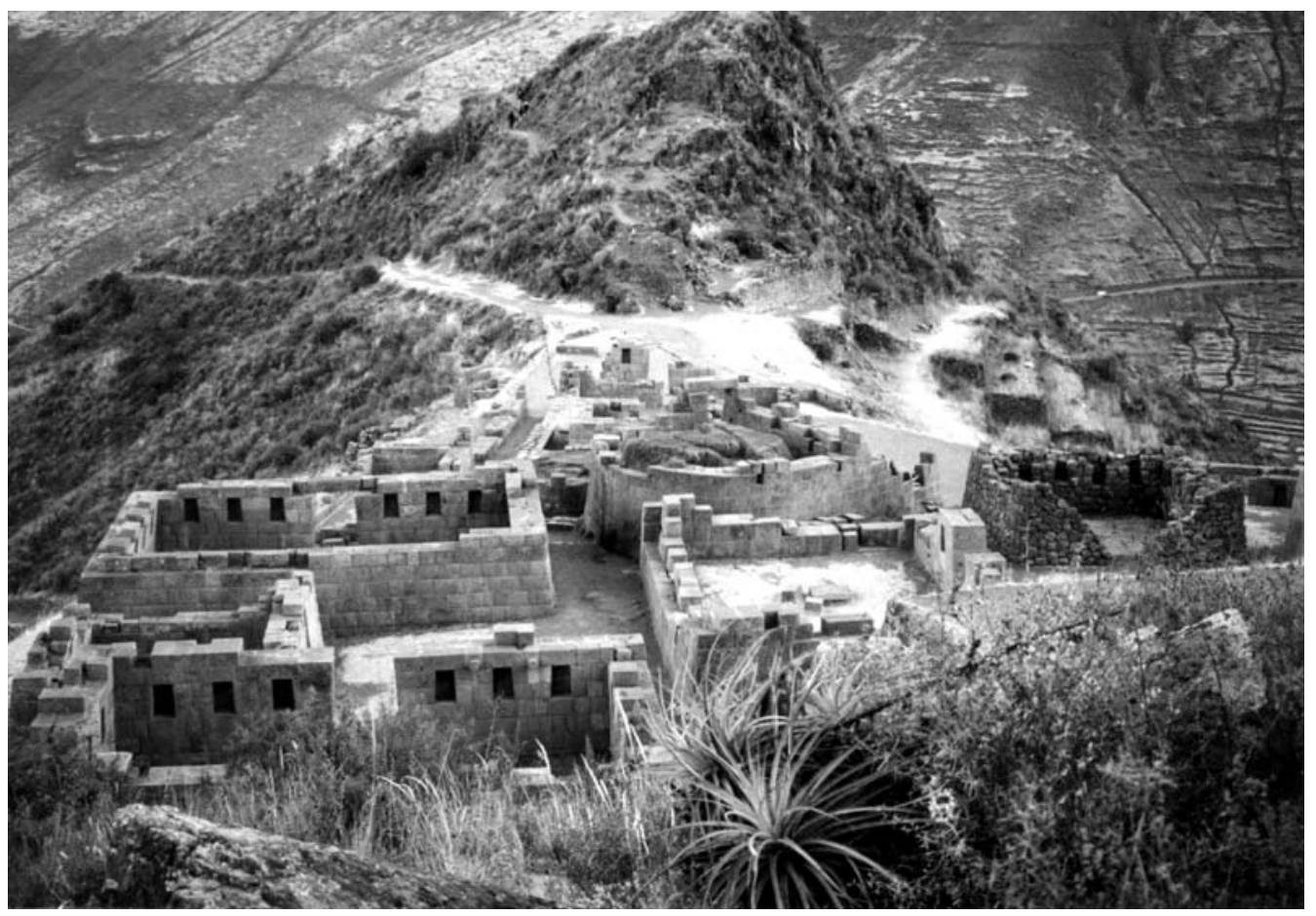

Figura 6. Pisac. Sector Intihuatana visto desde Inka Qonqorina (para ubicación ver Figura 2). (Foto T. Kusuda). 
Luego se agrega una porción del canal en la cual pasa por la sombra, con visibilidad reducida, cerca del área funeraria anterior, y paralelo al río. Con gran despliegue arquitectónico pasa al otro lado, al área del complejo Pisac o de la "huaca", donde parece cumplir otra función que es enmarcar el cerro con el agua "cultural", análoga al muro de circunvalación del lado oriental del cerro.

Al entrar en el sector del Intihuatana, la visibilidad se amplía notablemente cambiando de un eje oeste-este en el norte a un ángulo de suroeste o sureste, y la iluminación solar es constante durante todo el día. Al momento de entrar, aparecen fuentes labradas que conectan con otro canal corto que proviene de la misma "huaca", con lo cual la "huaca" contribuye con su esencia vital fusionándose con la de los ancestros, llamada illa. Es otro punto focal, probablemente el más importante del complejo y lugar de la realización de ritos que involucraban el agua, en los puntos remarcados por las "fuentes" pétreas, las rocas esculpidas y las instalaciones arquitectónicas del Intihuatana, el promontorio cónico al sur del Intihuatana y las construcciones en la parte alta hacia el norte. Entre la parte septentrional del Intihuatana y el promontorio mencionado el canal se voltea hacia el este y baja por la pendiente del lado oriental del cerro, en una serie de fuentes. Con ello el canal entra al espacio "económico" de la andenería, donde se despliega su energía fertilizadora, "repotenciada" ritualmente en el Intihuatana.

Una sectorización análoga se observa en el río Kitamayo. En su parte alta sirve de bocatoma para un canal que corre por su margen izquierda. A la altura de la estructura funeraria y con visibilidad a o de ella entra en una serie horizontal de cuatro fuentes (también hay cuatro fuentes del canal descrito al entrar en el sector Intihuatana) de donde se voltea hacia el este para dirigirse al sector Qantus Raqay. El río se encuentra canalizado y asociado a instalaciones arquitectónicas como series de plazas aterrazadas entre la estructura funeraria y el acueducto de Antachaca. A la altura del sector Intihuatana se abre la quebrada y el río entra en un sector de andenería donde cae en "dos pequeños saltos impresionantes, con más de cincuenta metros en total" (Angles 1970: 32), visibles solo en la época de lluvias.

Esta lectura padece de una cierta simplificación, ya que carece de una documentación más completa, así como la ausencia casi total de la contex- tualización debido a la ausencia de excavaciones en la parte occidental y la ausencia de informes acerca de los trabajos arqueológicos realizados en el complejo. Por otro lado, conduce a la formulación de conceptos de ancestralidad que involucran el paisaje y adquieren aspectos cosmológicos y cosmogónicos. Parece iniciarse con una relación entre grupos funerarios con vista al cerro sagrado, separado ( $₫$ ?) por el río Kitamayo, en la cual el aspecto solar no parece intervenir. El concepto incaico es mucho más complejo, ya que "culturiza" el paisaje al reorganizarlo por medio de instalaciones arquitectónicas que incorporan elementos "naturales" como el curso del agua y rocas. ¿El o los ancestro(s) se limitan a un personaje "real" como Pachacutec y/o se universalizan con el tiempo?

Este problema se relaciona con el tiempo de uso de este complejo que tampoco está definido hasta ahora. Existen algunas evidencias de construcciones que parecen ser posteriores por su carácter de elementos agregados. ${ }^{7}$

\section{b) Sipán}

Con el afán de presentar otros aspectos de ancestralidad quisiera concentrarme en los contextos funerarios excavados en Sipán, Lambayeque, costa norte del Perú, que pertenecen a la "cultura" Mochica, y situados aproximadamente entre 400 y 550 DC (Alva 2000, entre otros). ${ }^{8}$ Se trata de una superposición de seis plataformas, cada una con pozos insertados en la arquitectura que contienen varios individuos colocados en una cámara rectangular cubierta por vigas de algarrobo.

Estos contextos funerarios muestran diferencias en cuanto a la complejidad de su arquitectura funeraria, número y objetos asociados a los individuos y asociación a otros contextos funerarios o "repositorios". En este sentido existen tres contextos principales asociados a las plataformas o fases 1 , 4 y 6, conocidos también como el "Viejo Señor de Sipán” (T.3), "La Tumba Saqueada” y "Señor de Sipán” (T.1).

\footnotetext{
7 Estas reflexiones se deben a un proyecto realizado en 2000 y 2001, véase Zapata y cols. (2001 Ms); Kaulicke (2001b); Kaulicke y cols. (en prensa).

8 Sólo se dispone de un fechado C14 del sitio, por lo que las fechas son aproximativas; véase Kaulicke (en prensa).
} 
Otros contextos complejos se asocian a las demás plataformas con la excepción de la de la Fase 5: Fase 2 con T.9, Fase 3 con T.5, 7, 8 y 11, y Fase 6 con T.2,4 (i?), 10 y 12. En los contextos principales destaca un individuo principal en posición extendida, colocado en el centro de la cámara, normalmente dentro de un ataúd de madera (T.1 y Tumba Saqueada), en dirección norte-sur, con la cabeza hacia el sur. Este está cubierto por un fardo grande cuyas dimensiones dependen del número de capas de objetos que se ubican por encima y por debajo de él (en el caso de Sipán se trata exclusivamente de hombres). Estos objetos dejan reconocer un desarrollo paulatino desde la T.3 hasta la T.1, lo cual sugiere una secuencia de duración restringida; además de ello el material ubicado en las cámaras corresponde al de los repositorios asociados, en los cuales también se reconocen capas o niveles superpuestos. Estos últimos también suelen estar cubiertos con vigas de algarrobo.

Estas características sugieren series de secuencias relacionadas con la construcción: inserción del pozo en la plataforma, construcción de cámara, colocación de los individuos, animales y los objetos asociados, sello de vigas de troncos de árboles, relleno parcial, colocación de individuos posteriores, relleno del pozo. Paralelo, pero probablemente en uso después del relleno del pozo, se percibe la inserción de otro espacio destinado para la colocación de diferentes objetos y de animales e individuos sacrificados, el cual se sella también con vigas de algarrobo. Luego se procede a tapar toda la plataforma con el fin de construir otra encima. Pero existe también otra secuencia que es la del fardo del individuo cuya temporalidad es más conceptual que "real".

Quisiera comenzar la interpretación con esta última, pese a su carácter más especulativo y centrarme en el individuo de la T.3 y su tratamiento (Figura 7). Estaba envuelto en tres mantos grandes (Figura 7, 49-63-64), debajo del interior se encontraron dos "estandartes" volteados hacia el individuo (Figura 7, 59), pero la mayor parte del conjunto de objetos asociados se halló sobre el cuerpo. En la parte superior -la cabeza y el tórax- se concentraron grupos de pectorales, collares, narigueras y orejeras de conchas, y de oro, plata y cobre dorado (Figura 7, 30-39). Oro y/o cobre dorado y plata parecen formar alternancias significativas.
Son particularmente interesantes los collares, todos con 10 componentes, cabezas de diferentes formas que parecen formar una secuencia: jóvenes (debajo de la cabeza), felinos en oro, viejos en oro, viejos en plata, viejos con boca ligeramente felínica y felinos antropomorfizados con ojos alados y boca felínica. Las 10 narigueras son más difíciles de entender, ya que algunos carecen de motivos figurativos, otras con representaciones de aves, ¿aves con peces?, y dos llevan figuras antropomorfas con tocados muy elaborados. También se caracterizan por juegos de plata y de oro en combinaciones. En la parte central del cuerpo, abdomen y región púbica aparecen tres filas de sonajeros, oro, oro-plata-cobre dorado, las dos superiores con representaciones del "Degollador" (Figura 7, 40-42). Un protector coxal grande de oro con la misma representación yace por debajo de ellas (Figuras 7 y 9). En su mano derecha lleva una nariguera de plata y en la izquierda un lingote del mismo material.

Por último, sobre las piernas yacen cuatro pectorales de concha marina y otro protector coxal de plata (Figura 7, 52-55). Este parece formar un eje con otros de oro (centro) y plata (parte superior) con representación de iguanas. Sobre la cara del individuo yacía una máscara de cobre con collar de búho y objetos a modo de pectoral que terminan en tentáculos de pulpo. Sobre el cuerpo se colocaron varios "estandartes" con representaciones del "dios de los ulluchos" (Figuras 7, 59, y 8). Encima se halló el torso de un felino antropomorfo (Figuras 7, 9-28, y 10) y otra máscara con tocado (Figura 7, 4), que es otra versión de la que tiene collar de cabezas de búho y tocado, con cabeza de la misma ave. Sus orejeras corresponden a aquellas del individuo. A esa máscara le falta un ojo, el derecho en vez del izquierdo de la máscara funeraria. Superpuestas a otra cubierta de escamas de placas de cobre dorado aparecen dos figuras -un cangrejo antropomorfizado (Figura 7, 16) y un guerrero (Figura 7, 12)-, así como varios tocados y la cabeza del felino antropomorfizado. Otra figura de una divinidad antropomorfa, así como una serie de tocados y máscaras completan el conjunto (Figura 7, 2-8). Como último objeto, encima del fardo, se colocó otro collar con arañas (Figura 7,1 ).

Esta secuencia parece corresponder a una serie de transformaciones que se inician con el pase de la juventud a la vejez, de ahí a la felinización y, 


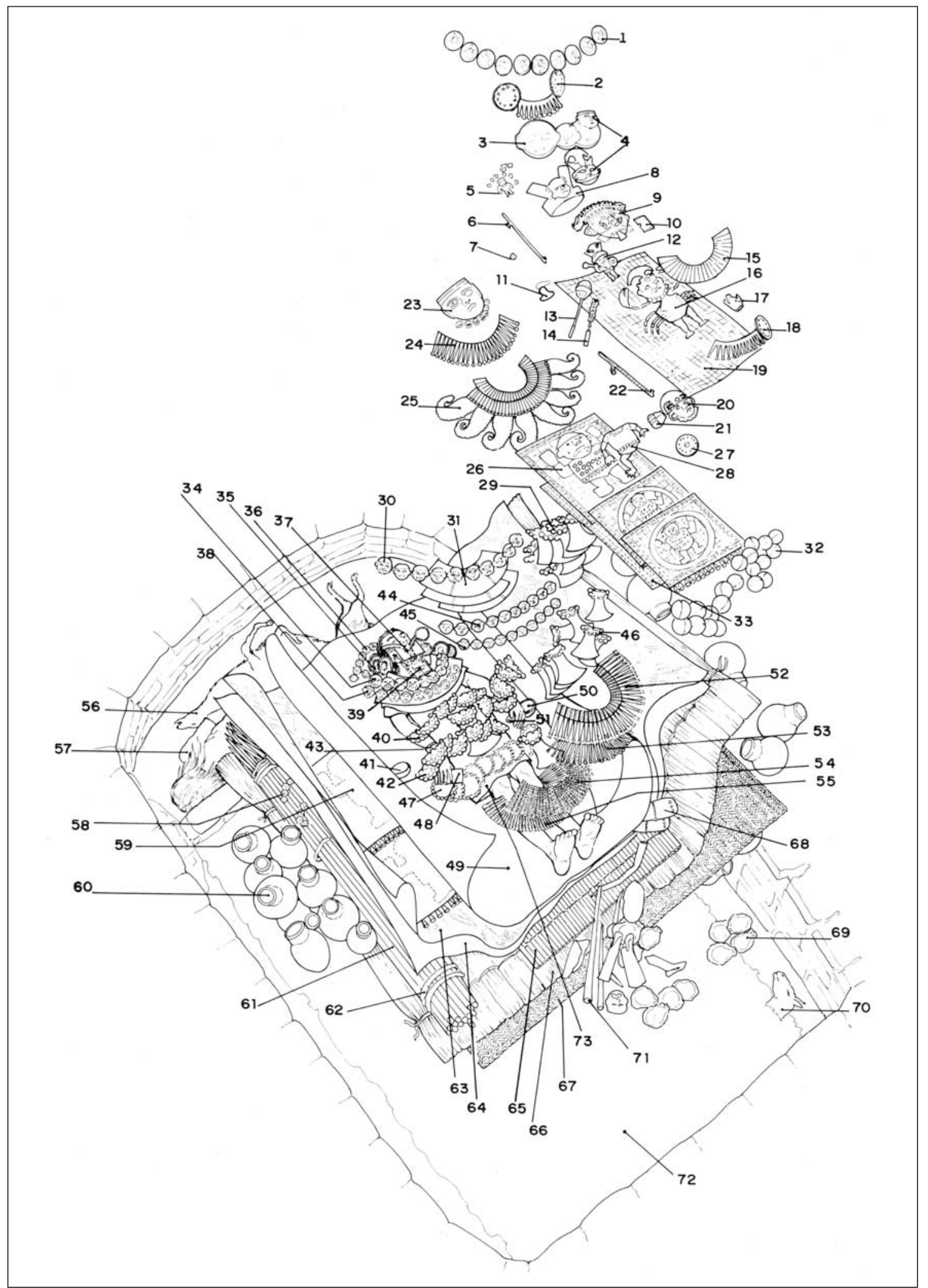

Figura 7. Dibujo con ubicación de las piezas asociadas al "Viejo Señor de Sipán" (T.3). (Tomado de Alva 1994, dibujo 46). 


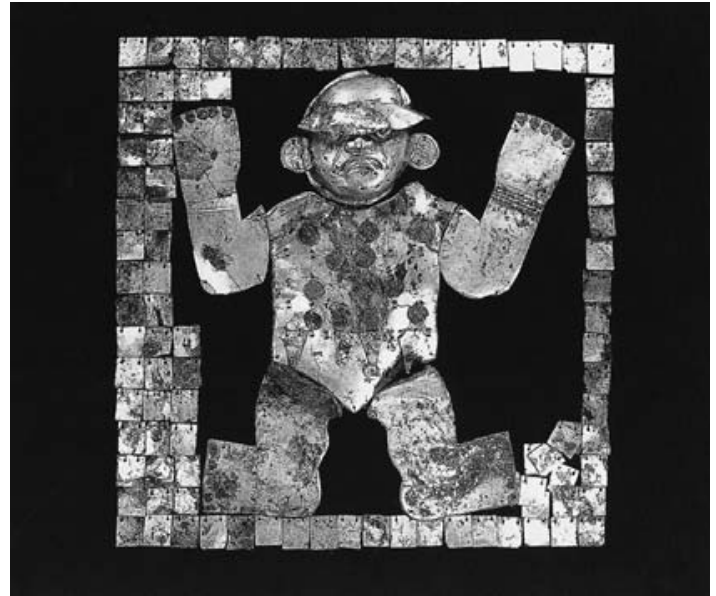

Figura 8. "Estandarte" de T.3 (para ubicación ver Figura 7, 26). (Tomado de Alva 1998, lámina 287).

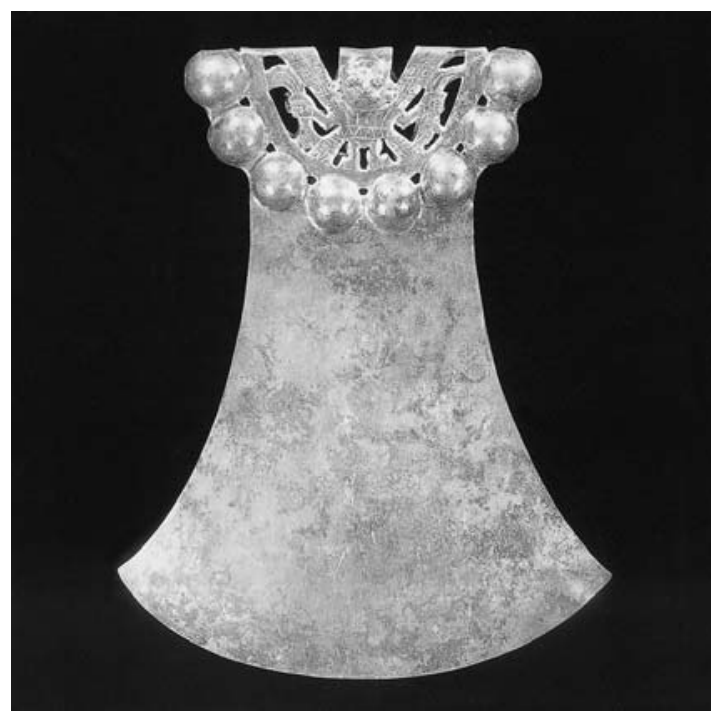

Figura 9. Protector coxal de T.3 (para ubicación ver Figura 7, debajo de 7, 40-42). (Tomado de Alva 1998, lámina 269).

finalmente, a su conversión en dios o ancestro divinizado, apoyado por dioses como el "Degollador" y quizá el "Dios de los Ulluchos". En esta nueva identidad inicia su viaje por un ambiente acuático. Con armas y tocados cambiantes se enfrenta a adversarios como el felino y el cangrejo antropomorfizados, proceso en el cual otra vez recibe ayuda de otros seres.

Finalmente, el collar de las arañas debería indicar su ascenso al "cielo" en calidad de ancestro. Esta interpretación se apoya en representaciones narrativas en la cerámica con pintura de línea fina

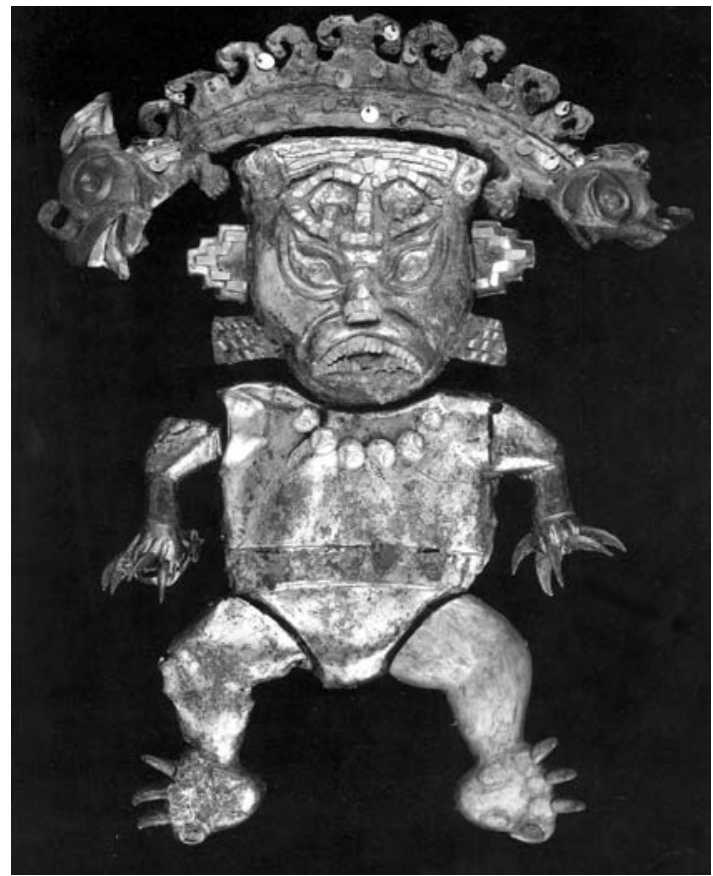

Figura 10. Felino antropomorfo de T.3 (para ubicación ver Figura 7, 9-28). (Tomado de Alva 1994, lámina 173).

encontrada en otros contextos mochicas (Kaulicke 2000: 278-280). A este proceso de la transformación se suma en contextos posteriores un gran despliegue de "personal" (tanto ficticio en forma de vasijas como en individuos sacrificados o acompañantes muertos con anterioridad u otros en contextos funerarios de la misma fase) que refleja tanto la vida cortesana como un contingente importante de "prisioneros" cuyo destino era el sacrificio y la extracción de su sangre como bebida de los dioses (y del mismo ancestro). Refleja además la necesidad de una atención constante que sobrepasa la atención directa en el contexto funerario propiamente dicho, aunque los acompañantes "reales" y "ficticios" evidentemente cumplían su tarea en forma permanente. Es de suponer que los "repositorios" al lado de la estructura funeraria cumplían funciones parecidas, quizá en forma de ritos cíclicos.

Estos ciclos de transformación, tanto "internos" (materializados en la cámara sellada) como "externos" (formación de "niveles" en los repositorios) se insertan en otros mayores. La superposición de arquitectura monumental que es una característica muy difundida desde el Período Arcaico Tardío parece reflejar ciclos propios en el 
sentido de un "enterramiento" con el edificio posterior como "regeneración" del anterior, lo cual muestra paralelos al ciclo de la vida humana y su transformación después de la muerte.

En el caso de Sipán -y, probablemente, en muchos otros contemporáneos, anteriores y posteriores- esta superposición se manifiesta como una especie de "repotenciamiento" de los ancestros, quienes se refuerzan con el poder de sus antecesores dentro de una temporalidad cíclica. Cabe preguntarse, como en el caso de Pisac, si estos mecanismos de la ancestralización y su carácter cíclico conducen al olvido o al concepto de un ancestro tan despersonalizado que se convierta en ancestro "universal" o si llevan a la percepción de una serie de ancestros diferenciados y perpetuados como tales pese a su "desaparición" física paulatina.

\section{Conclusiones}

Si bien los dos casos presentados, evidentemente, no pueden pretender definir mecanismos de memoria representativos para todo el pasado prehispánico, sirven para señalar algunas pautas hacia su significado generalizado. En primer lugar, la ancestralización en su aspecto corporal (Sipán) y en su incorporación "funcional" en el paisaje (Pisac) aparentemente es un motor poderoso de las élites en su afán de legitimación y de perpetuación. Involucran los actos del gobernante hacia su propia ancestralización en una especie de fusión entre política e ideología, en la cual se entremezcla el actuar político con la interacción de sus antepasados, con otras palabras, una especie de res gestae que se materializa en la modificación del espacio social y en ritos y/o textos que sirven para perpetuar la memoria del gobernante (véase caso de los incas) como "persona" y como ancestro.
En los contextos funerarios de Sipán se perciben diferencias (¿aspectos personales?) en el tratamiento dentro de una secuencia, probablemente corta (¿cuatro generaciones?), pero prevalece la transformación en ancestro desde un espacio cerrado a otro público, con lo cual se enfatiza su reinserción en la sociedad. Esta ancestralización, por lo tanto, tiene un carácter dinámico, sostenido por una ideología de élite, cuyo funcionamiento depende del surgimiento y del ocaso de ella. En los casos de los incas y de la élite de Sipán (y muchos otros) se trata de ciclos relativamente cortos que se relacionan tanto con desplazamientos como con replazamientos de la misma élite o cambios de élite.

Por otro lado, la legitimación no se limita a la definición de los orígenes de la ancestralización en sociedades presentes, sino se proyecta a un pasado más remoto. Esto se plasma tanto en la reocupación funeraria de edificios abandonados, cuyo funcionamiento data de tiempos "remotos" (véase relación de los incas del Cuzco con Tiwanaku) o recientes (véase caso de Pisac), sino también en la retención de temas figurativos, frecuentemente denominados "arcaísmos". Ya que los soportes suelen pertenecer a contextos funerarios, estos "arcaísmos" podrían entenderse como retención de la lógica de la transformación en ancestros, por más que ésta pueda haber adquirido facetas distintas, ya que la meta evidentemente se mantiene vigente.

Todo ello implica además que el o los pasado(s) no se limitan a una memoria "psicológica" o cuasi "genética" que se perpetúa en forma básicamente inalterada. Las memorias ejemplificadas exhiben todas las características de una memoria cultural pese a que sus textos no nos "hablan" (¿aún?).

\section{REFERENCIAS CITADAS}

ABERCROMBIE, T. A., 1998. Pathways of memory and power. Ethnography and History among an Andean people. University of Wisconsin Press, Wisconsin.

ALVA, W., 1994. Sipán. Colección Cultura y Arte del Perú, Lima.

1998. Sipán. Descubrimiento e investigación. Lima.
2000. The royal tombs of Sipán: Art and power in Moche society. En Moche art and archaeology in Ancient Peru, J. Pillsbury (Ed.), pp. 223-245, Yale University Press, New Haven / Londres.

ANGLES, V., 1970. P'isaq. Metrópoli Inka. Industrialgráfica, Lima. 
ASSMANN, J., 2000a. Das kulturelle Gedächtnis. Schrift, Erinnerung und politische Identität in frühen Hochkulturen. $3^{\mathrm{a}}$ edición, Verlag Beck, München.

2000b. Religion und kulturelles Gedächtnis. Verlag Beck, München.

BAUER, B. y C. STANISH, 2000. Ritual and pilgrimage in the Ancient Andes: The Islands of the Sun and the Moon. University of Texas Press, Austin.

BETANZOS, J. de, 1987 [1551]. Suma y narración de los Incas, Transcripción, notas y prólogo por M. del C. Martín Rubio. Atlas, Madrid.

BRADLEY, R., 2000. An archaeology of natural places. Routledge, Londres.

BUCK, F., 1935. Cuzco-Tiahuanacu. Revista del Museo Nacional IV (1): 111-114.

DUVIOLS, P., 2003. Procesos y Visitas de Idolatrías. Cajatambo, siglo XVII. Colección Clásicos Peruanos, Pontificia Universidad Católica del Perú / Instituto Francés de Estudios Andinos, Fondo Editorial PUCP, Lima.

HALBWACHS, M., 1975 [1925]. Les cadres sociaux de le mémoire. Arno Press, Nueva York.

1991. On collective memory. L.A. Coser (Ed.). University of Chicago Press, Chicago / Londres.

JULIEN, C., 2000. Reading Inca History, University of Iowa Press, Iowa.

KAUliCKE, P., 1997. La muerte en el Antiguo Perú. Contextos y conceptos funerarios: Una introducción. Boletín de Arqueología PUCP 1: 7-54.

-1998. La muerte del Inca. Aproximaciones a los ritos funerarios y la escatología Inca. En Actas del IV Congreso Internacional de Etnohistoria, III, pp.134-171, Fondo Editorial PUCP, Lima.

-2000. Memoria y muerte en el Perú Antiguo. Fondo Editorial PUCP, Lima.

2001a. Cronología, identidad, urbanismo y Estado en los Andes Centrales y Sur Centrales entre los siglos V a X DC: Algunas reflexiones finales. Boletín de Arqueología PUCP 5: 481-529.

_ 2001b. La función cultural de las obras hidráulicas en el tiempo de los incas. Boletín de la Sociedad Geográfica de Lima 114: 201-216.

- En prensa. La cronología arqueológica y los fechados ${ }^{14}$ C. Actas del Seminario Internacional sobre datación radiocarbónica, 2002, Lima.

KAULICKE, P.; R. KONDO, T. KUSUDA y J. ZAPATA, en prensa. Agua, ancestros y la arqueología de paisaje. Boletín de Arqueología PUCP 7.

KLEIN, G. L., 2000. On the emergence of memory in historical discourse. Representations 69: 127-150.
KOSELLECK, R., 1993. El futuro pasado: Para una semántica de los tiempos históricos. Paidós, Barcelona / Buenos Aires / México D. F.

LE GOFF, J., 1991. El orden de la memoria: El tiempo como imaginario. Paidós, Barcelona.

NILES, S., 1999. The shape of Inca History. Narrative and architecture in an Andean Empire. University of Iowa Press, Iowa City.

OESTERREICHER, W., 2001. Sprachwandel, Varietätenwandel, Sprachgeschichte. Zu einem verdrängten Theoriezusammenhang. En Varieties and consequences of orality and literacy, U. Schaefer y E. Spielmann (Eds.), pp. 217-248. Narr, Tübingen.

OLICK, J. F. y J. ROBBINS, 1998. Social memory studies: From "Collective Memory" to the Historical Sociology of mnemonic practices. Annual Review of Sociology 24: 105-140.

PAREDES, M., 1999. Registro informatizado de restos prehispánicos en el centro histórico de Cusco. Diagnóstico e interpretación. Tesis inédita para optar al título profesional de Licenciatura en Arqueología, Universidad Nacional San Antonio de Abad del Cusco, Cusco.

RAMIREZ, S. E., 2002. El mundo al revés: Contactos y conflictos transculturales en el Perú del siglo XVI. Fondo Editorial PUCP, Lima.

SARMIENTO DE GAMBOA, P., 1960 [1572]. Historia Indica. Biblioteca de Autores Españoles 135, pp. 193-279. Ediciones Atlas, Madrid.

SILLAR, B., 2002. Caminando a través del tiempo: Geografías sagradas en Cacha/Raqchi, departamento del Cuzco (Perú), Revista Andina 35: 221-245.

SQUIER, E., 1877. Peru: Incidents of travel and exploration in the Land of the Incas. Harper \& Brothers, Nueva York.

STANISH, C., 2003. Ancient Titicaca: The evolution of complex society in Southern Peru and Northern Bolivia. University of California Press, Los Angeles.

VALCARCEL, L. E., 1935. Sajsawaman redescubierto. Revista del Museo Nacional IV (2): 161-203.

VAN DER GUCHTE, M. J. D., 1990. "Carving the world": Inca monumental sculpture and landscape. Tesis doctoral inédita, University of Illinois at Urbana-Champaign.

WIENER, C., 1880. Pérou et Bolivie. Récit de voyage. Librairie Hachette, Paris. Traducción de E. Rivera, Travaux de l'Institut Français de Etudes Andines 56 (1993), Lima.

ZAPATA, J.; P. KAULICKE, T. KUSUDA, R. KONDO, H. HARADA y A. SAKODA, 2001 Ms. Report of field investigation on hydraulic works in Machu Picchu and Pisac. Informe (original en inglés) entregado al INC, Cuzco. 